\title{
ADMINISTRATIVE SUPERVISORS' RATING OF DESKTOP PUBLISHING COMPETENCIES POSSESSED BY OFFICE TECHNOLOGY AND MANAGEMENT GRADUATE WORKERS IN NORTH-WEST NIGERIA POLYTECHNICS
}

\author{
Ado Garba Gude \\ Department of Office Technology and Management, Kano State Polytechnic, Kano \\ State Nigeria
}

*Corresponding Author email: adogarba20@gmail.com

Article History

Submission: May 21, 2020

Revised: June 13, 2020

Accepted: June 29, 2020

\begin{abstract}
This study on supervisors' rating of Office Technology and Management (OTM) graduate workers competencies in using MS Desktop publishing in North-West Nigerian polytechnics was necessitated by persistent complaints from employers of labour that OTM graduate workers do not perform as expected in the current era of technology. One research question guided the study, and two null hypotheses were tested at 0.05 level of significance using T-test. Descriptive survey research design was used for the study. The population of the study constituted 378 supervisors in state and federal polytechnics in North-West Nigeria. The population was used as the sample. A structured 5-point rating scale questionnaire containing 16 items were developed and validated by experts. Reliability of the instrument was established using split half method and Pearson Product Moment Co-efficient Correlation formula and obtained a reliability co-efficient value of 0.77 . The data collected was analysed with mean and standard deviation to answer the research questions and determine homogeneity or otherwise of the respondents. Findings revealed that administrative supervisors in polytechnics in North-West Nigeria rated their Office Technology and Management (OTM) graduate workers as fairly possessing desktop publishing competencies. Gender and the ownership of the institutions have no influence on the respondents' ratings. Based on the findings, it was concluded that OTM graduate workers in Polytechnics in North-West Nigeria, do not possess the relevant desktop publishing competencies. It was recommended that The OTM graduate workers should engage in in-service training programmes to improve their competencies in desktop publishing. The administrative supervisors should recommend approval of in-service training for their OTM graduate workers to enhance their computer application competencies.
\end{abstract}

Keywords: Competencies, Desktop Publisher, North-West Nigeria, Rating

Abbreviations: NIL

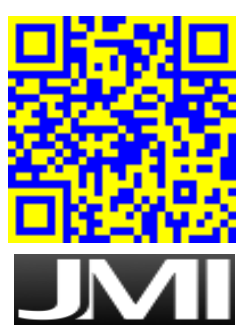

Journal of Management Info. Vol. 7 No. 2, 2020: pp. 135-144 Doi: 10.31580/jmi.v7i2.1423 www.readersinsight.net/jmi

\section{Readers Insight}




\section{INTRODUCTION}

Office Technology and Management (OTM) graduates are referred to as employees who graduated from the Nigerian Polytechnics, having undergone the training of office technology and management curriculum and have satisfied the requirement of graduation at either National or Higher National Diploma level. The graduates are trained to provide secretarial services using modern office automation tools to enhance effective service delivery for the achievement of the organizational goals. Adelekin (2009) was of the view that, for the Office Technology and Management graduates to be competent in their works, they must be provided with necessary skills and modern facilities for training. Agoha ( 2011) asserted that the contemporary skills expected of OTM graduates are those that would make them well-fit, competent and independent in the technologies of the 21st centuries.

However, the designation of OTM graduates in the global age appeared doubtful. The reason for the doubt was the replacement of old curriculum which was dominated by shorthand and typewriting with relatively new office technology and management curriculum that focused on computer based training skills. Ahakannah, L.I.\& Chukwumezie (2008) mentioned that the new Office Technology and Management curriculum, proposes the designation of business communication manager, business system technologist or office systems manager. Okoro, F. \& Asogwa, (2012) added on the views of Ahakannah and Chukwumezie, that the designations of OTM graduates be change to office technologist. Alfred (2014) opined that OTM graduate, even though advertisement for jobs still focused on secretaries, lack occupational nomenclature. This presumes that, the essential office worker has no clear designation. Going by the National Board for Technical Education, NBTE ( 2004) curriculum and course specification, one of the objectives stated categorically is to produce graduates of ND/HND OTM who should fit properly into the modern office of any kind and perform professionally the functions of a secretary. Hence, this cleared all doubts on the designation of OTM graduates workers. In the context of this paper, office technology and management graduate worker is the one who is proficiently trained, with NBTE curriculum in the Nigerian polytechnics to acquire either National or Higher National Diploma certificate, with the aim to serve as a secretary.

An administrative supervisor is a higher officer in an organization who mentors the works of subordinates in the work place. He manage their activities towards achieving the set goals and objectives of the organization. James 1967) explained that an administrative supervisor, being a professional employee, is in charge of developing and promoting harmonious working relationship among his subordinates. This means that administrative supervisors are in the better position to assess the level at which 
the graduate workers possess the required competences to effectively do their jobs. Abdullahi (2010) maintained that the administrative supervisor is a person who direct and oversees works done by others. Since administrative supervisors are saddled with supervision, they can participate in activities associated with human resource management in organizations. This study viewed administrative supervisors as principal officers who mentor secretaries, otherwise office technology and management graduate workers in the Nigerian polytechnics.

Competency is the ability to carry out responsibility as expected. It is the acquired knowledge, skills and procedure that enable workers to meet established performance criteria in organizations. Okolocha, C.C. \& Olanye (2015) viewed computer application competency as the ability to use correct procedure to manipulate the computer as required in order to obtain results. Among the computer applications, MS publisher is inclusive.

\section{Statement Of the Problem}

In today's technological era, there is the need for graduates to possess ICT skills in order to secure and perform well in employment. In line with this, office technology and management (OTM) graduates are expected to possess both practical and theoretical skills in ICT based courses of the curriculum objectives. However, there is an emerging challenge regarding the OTM graduate workers exposure on desktop publishing application. This application is one of those that the graduates receive training, with the expectation of offering better performance in the office. Grace (2015) observed that, most OTM graduate workers in south-west of Nigeria were not performing as expected due to either inadequate modern training facilities or teachers' exposure to use modern machines. This, according to the author, will surely mar the environmental replication of work in their training institutions. This stimulated some supervisors of the products of this programme, after assessing the competencies of the graduates on desktop publishing, to recommend that greater emphasis be placed on teaching the computer based courses so that the graduates can become more competent in their use.

The problem of this study is that, the Polytechnics that celebrated the graduation of these graduates all the times do not seem to have assessed the knowledge of their competencies level on desktop publishing to confirm the view of other employers. Since the Polytechnics in the north-west Nigeria employ some of these OTM graduate workers, it is considerably necessary that their administrative supervisors should rate them on the desktop publishing which is very vital to their regular functions, to ascertain their competencies for an improved productivity in an office. 


\section{PURPOSE OF THE STUDY}

The main purpose of the study was on administrative supervisors' assessment of computer applications competencies possessed by OTM graduate workers' in NorthWest Nigeria Polytechnics. Specifically, the study determined the administrative supervisors' assessment of OTM graduate workers competencies possessed in the desktop publishing.

\section{RESEARCH QUESTIONS}

What is the administrative supervisors' assessment of desktop publishing competencies possessed by OTM graduate workers in Polytechnics in North-West Nigeria?

\section{NULL HYPOTHESES}

The following null hypotheses were tested at 0.05 level of significance:

1. Male and female administrative supervisors in polytechnics in North-West Nigeria do not differ significantly in their mean ratings on desktop publishing competencies possessed by OTM graduate workers.

2. Administrative supervisors in federal and state polytechnics in North-West Nigeria do not differ significantly in their mean ratings on desktop publishing competencies possessed by OTM graduate workers.

\section{LITERATURE REVIEW/MATERIALS}

Desktop publishing is one of the applications of Microsoft office which is used to create various publications. It is used to create fliers, calendars and newsletters. Microsoft (2006) mentioned that desktop publishing consists of what you see is what you get $\{$ WYSIWYG $\}$ page layout that creates and prints publication documents on a computer. The author added that desktop publishing methods provide more control over design, layout, and typography than word processing. Okoye ( 2012) stated that, desktop publishing skills are used to create graphic for point of sale displays, promotional items, trade show exhibits, retail package designs and outdoor signs. This implies the relevance of the application for achieving competency by OTM graduates worker is that he can export and import information from other applications. In the same vein, Mcgoldrick in Ndinechi \& Ementa (2013) opined that desktop publishing enable the secretary manipulate, typeset, align images, graphic and page layout. In another view, Anigbogu \& Anigbogu (2010) added that desktop publishing enables the secretary to layout the text and graphic on the screen to see how the text would look like. Therefore, a proper knowledge of desktop publishing course unit by OTM graduate 
workers will enable them to competently perform in an office as expected. The reviewed study was done on the followings;

CHUKWUMEZIE (2006) CARRIED OUT A STUDY ON COMPUTER SKILLS NEEDED BY PERSONAL SECRETARIAL ASSISTANTS IN PRIVATE LIMITED LIABILITY COMPANIES IN THE SOUTH-SOUTH NIGERIA.

The purpose of the study was to assess the computer skills needed by personal secretarial assistants in private limited liability companies in the south-eastern Nigeria. The study stressed that computer knowledge is the necessary requirement for the secretary to be employed. The researcher noted that most studies confirmed the competencies of secretaries in the use of word processing and spreadsheet applications in the south-east Nigeria. But there is no much evidence to show that secretaries need the required skills in the use of desktop publishing. ANOVA was the tool for testing the null hypothesis. The analysis indicated the need for secretaries in South-east Nigeria to possess desktop publishing skills. The finding shows that with desktop publishing, secretaries can create newsletters, brochures and calendars. The reviewed study and the present one studied desktop publishing as it affects secretaries. Both researches differed in the geographical location.

HARO \&\& NWAZOR (2016) SUPERVISORS RATING OF COMPETENCIES POSSESSED BY OFFICE TECHNOLOGY AND MANAGEMENT GRADUATES WORKERS IN PUBLIC ORGANIZATIONS IN KATSINA STATE.

The researchers adopted a survey research design and z-test for the null hypothesis. The purpose was to determine supervisors' rating of competencies possessed by OTM graduate workers in public organization in Katsina state. The study suggested that, with advent of information and communication technology, organizational effectiveness depends on its secretarial services. Modern work now goes beyond manual processing of information. The researchers observed that desktop publishing competencies possessed by the secretaries could not be ascertained without empirical study. The analysis revealed a negative response from the respondents which means that there were some challenges in the use of desktop publishing as rated by the supervisors in Katsina State of Nigeria. However, previous study was narrowed to one state while the present study covered seven states in the North-west Nigeria. Additionally, both researches differed in the population.

\section{CHUKWUKELU AND Ile ( 2018) OfFICE COMPETENCIES REQUIRED OF BUSINESS EDUCATION GRADUATES FOR EFFECTIVE PERFORMANCE IN MOdERn OfFICE IN IMO STATE, NigerIA.}

The researchers adopted a descriptive survey research design. The rational for the study was to find out the Office competencies required of business education graduates for effective performance in Modern Office in Imo State, Nigeria. Two research questions and two null hypotheses were employed in the study. The 
instrument for data collection was a structured four point rating scale questionnaire. Data were analysed using mean and standard deviation, while the null hypotheses were tested at 0.05 level of significance using $z$ test. The researchers concluded that business education students were not equipped with necessary competencies. The researchers recommended that lecturers should emphasise on equipping students with desktop publishing competencies for effective performance. However, the previous research was carried out in one state out of the 36 states of Nigeria, z-test was also used. The present study was conducted in seven states of Nigeria and t-test was used. But both researches were similar since they tried to assess competencies in using desktop publishing. Generally, none of the reviewed studies above used t-test in the hypothesis testing. This lapse created a gap which the present study filled.

\section{METHODOLOGY/MATERIALS}

Descriptive survey research design was used for the study. The area was North-West Nigeria consisting of seven states namely; Kano, Katsina, Kaduna, Kebbi, Jigawa, Sokoto and Zamfara States in Nigeria. Population consisted of 378 administrative supervisors (Rectors, Registrars, Directors, Senior Administrative officers, Cocoordinators and Heads of Departments and Units) in all the 10 polytechnics. The entire population was studied without sampling. The instrument for data collection was a 5-point Likert type structured questionnaire titled "Office Technology and Management Graduate Workers Competencies Questionnaire (OTMGWCQ)". The instrument was validated by three experts while the reliability co-efficient value of 0.77 was obtained using split half method with Pearson Product Moment Correlation Coefficient. The researcher administered the instrument with the help of three research assistants who work in the polytechnics and 325 copies (representing 86 percent) were retrieved and used for analysis. Data collected were analyzed using mean and standard deviation to answer the research questions and determine the closeness of the respondents' mean ratings, while t-test was used and tested the null hypotheses at 0.05 level of significance. A null hypothesis was accepted where the $p$-value was equal to or greater than the alpha level of 0.05 and rejected where the $p$-value was less than the alpha level. The analysis was done with the Statistical Package for Social Sciences (SPSS) version 16.

\section{RESULTS AND FINDINGS}

Table I. Respondents' Mean Ratings on Desktop Publishing Competencies Possessed by OTM Graduate Workers in North-West Nigeria Polytechnics

\begin{tabular}{lllll}
\hline S/N & Desktop publishing competencies & Mean & SD & Remarks \\
\hline & Ability to: & & & \\
1 & Create a publication & 2.52 & 1.42 & Moderately Possessed \\
\hline
\end{tabular}




\begin{tabular}{|c|c|c|c|c|}
\hline 2 & Format a publication & 2.43 & 1.46 & Fairly Possessed \\
\hline 3 & Use tool bars & 2.73 & 1.62 & Moderately Possessed \\
\hline 4 & Apply master page & 2.35 & 1.48 & Fairly Possessed \\
\hline 5 & Work with a design checker and options & 2.92 & 1.76 & Moderately Possessed \\
\hline 6 & Use lay out guides & 2.38 & 1.50 & Fairly Possessed \\
\hline 7 & Create banners & 2.30 & 1.38 & Fairly Possessed \\
\hline 8 & Create business and complementary cards & 2.30 & 1.38 & Fairly Possessed \\
\hline 9 & Create calendars & 2.27 & 1.41 & Fairly Possessed \\
\hline 10 & Create envelopes & 2.26 & 1.40 & Fairly Possessed \\
\hline 11 & Design letter head & 2.44 & 1.47 & Fairly Possessed \\
\hline 12 & Create website & 2.21 & 1.36 & Fairly Possessed \\
\hline 13 & Create resume & 2.30 & 1.40 & Fairly Possessed \\
\hline 14 & Import pictures from other sources & 2.40 & 1.44 & Fairly Possessed \\
\hline 15 & Import text from word documents & 2.34 & 1.46 & Fairly Possessed \\
\hline \multirow[t]{2}{*}{16} & Group or ungroup objects & 2.29 & 1.58 & Fairly Possessed \\
\hline & Grand Mean & 2.40 & & Fairly Possessed \\
\hline
\end{tabular}

Source: Field survey

Table 1 shows that the administrative supervisors rate their OTM graduate workers as moderately, possessing three of the listed desktop publishing competencies with mean scores of 2.52, 2.73 and 2.92. The remaining 13 competencies have mean ratings ranging from 2.21 to 2.44 showing that the OTM graduate workers fairly possessed them. The grand mean score of 2.40 indicates that the administrative supervisors rated OTM graduate workers as fairly possessing desktop publishing competencies. Standard deviations shows that the respondents' are homogenous in their ratings.

Table II. Summary of T-test Analysis of Male and Female Respondents' Mean Ratings on Desktop Publishing Competencies Possessed by OTM Graduate Workers in North-West Nigeria Polytechnics.

\begin{tabular}{|c|c|c|c|c|c|c|c|c|c|}
\hline Group & $\mathrm{N}$ & $\bar{x}$ & SD & $d f$ & $\begin{array}{c}\text { Standard } \\
\text { Error }\end{array}$ & t-cal & P-value & $\alpha$ & Decision \\
\hline \multirow[t]{2}{*}{ Male } & 217 & 2.18 & 1.34 & & & & & & Not \\
\hline & & & & 323 & 0.07 & -0.34 & 0.07 & 0.05 & significant \\
\hline Female & 108 & 1.99 & 1.29 & & & & & & \\
\hline
\end{tabular}

Table 2 reveals $p$-value of 0.07 which is greater than the alpha value of 0.05 at a degree of freedom of 323. The t-value shows -0.34 . Therefore, the null hypothesis is accepted. In essence, there is no significant difference on the mean ratings of male and female administrative supervisors in polytechnics in North-West Nigeria in desktop publishing competencies possessed by their OTM graduates employees.

\section{NULL HYPOTHESIS 2}

Administrative supervisors in federal and state polytechnics in North West Nigeria do not differ significantly in their mean ratings on desktop publishing competencies possessed by their OTM graduate workers. 
The result of the t-test conducted in respect of this hypothesis is presented in Table 3

Table III. Summary of T-test Analysis of Mean Ratings between Respondents' From Federal and State Owned Polytechnics on Desktop Publishing Competencies Possessed byOTM Graduate Workers in North-West Nigeria Polytechnics.

\begin{tabular}{lccccccccc}
\hline Group & $\mathbf{N}$ & $\overline{\mathbf{X}}$ & $\mathrm{SD}$ & $\mathrm{df}$ & $\begin{array}{c}\text { Standard } \\
\text { Error }\end{array}$ & $\mathrm{t}$-cal & P-value & $\boldsymbol{\alpha}$ & Decision \\
\hline Federal & 145 & 1.65 & 0.07 & & & & & & \\
& & & & 323 & 0.07 & -0.16 & 0.05 & 0.05 & $\begin{array}{c}\text { Not } \\
\text { significant }\end{array}$ \\
State & 180 & 2.49 & 0.39 & & & & & & \\
\hline
\end{tabular}

Table 3 shows the calculated t-value of -016 at 323 degree of freedom with $p$-value of 0.05 which is equal to alpha value of 0.05 . This means that the null hypothesis is accepted a phenomenon that implies that administrative supervisors of federal and state polytechnics in North West Nigeria do not differ significantly in their mean ratings of OTM graduates workers competencies in desktop publishing.

\section{DISCUSSION}

The finding of the study in desktop publishing application revealed that OTM graduate workers in polytechnics in North-West Nigeria were fairly competent. This finding is in line with Garba (2012) who investigated and reported that OTM students (potential graduate workers) in the polytechnics in North-West Nigeria were barely proficient in their self-rating in desktop publishing. This was justified by Haro, D.M.\& Nwazor, (2016) that OTM graduate workers in public organization in Katsina State were rated by their supervisors as possessing desktop publishing competencies at a low extent. This finding could be as a result of non-utilization of the graduate workers in the use of the application. It may also be as a result of nonchalant attitude by the graduates for self-development on the application due to the fact that assignments relating to the application were not assigned by their supervisors. As reported by Chukwumezie (2006) that managers in private limited liability companies in South-East zone considered desktop publishing sub-skills highly needed for their OTM graduate workers.

The finding further revealed that administrative supervisors in polytechnics in NorthWest Nigeria do not differ significantly in their mean ratings on the competencies of OTM graduate workers in desktop publishing application. It is also in consonance with Haro and Nwazor (2016) that discovered no significant difference exist on the mean ratings of supervisors of public organizations in Katsina State regarding the OTM graduate workers competency possessed in using desktop publishing application. However, the finding is in disagreement with Chukwumezie (2006) who observed that 
significant difference exit on the managers' responses on their mean ratings on desktop publishing sub-skill needed by personal secretarial assistants.

\section{CONCLUSION}

Based on the findings of this study, it is concluded that OTM graduates workers in North-West Nigerian Polytechnics do not possess relevant skills in desktop publishing application. The tested hypotheses revealed that gender and the institution ownership did not influenced the respondents' opinions showing particularly that there is an imbalance in availability of utilizing of ICT resources between the institutions. The study recommends that, Office Technology and Management graduate workers should engage in in-service training programmes to improve their competencies in desktop publishing. The administrative supervisors should recommend approval of inservice training for their OTM graduate workers to enhance their computer application competencies. The management of the institutions covered in this study should ensure that ICT resources are available and functional for use by their OTM graduates workers and for training of students.

\section{Acknowledgements}

This research work is sponsored by Tertiary Education Trust Fund (Tetfund) and supported by Kano State Polytechnic, Kano Nigeria.

\section{Reference:}

Abdullahi, K. (2010). Supervisor and work ethics: An overview. Hassan Usman Katsina Journal of Administration and Management Sciience, 1(4), 95-102.

Adelekin, T. . (2009). Issues and trends in teaching and learning of office technology and management. Book of Reading in Business Education, 6(2), 209-220.

Agoha, G, C. (2011). Skill acquisition and entrepreneurship education: The basic requirements for secretarial and business education students. Book of Reading in Business Education, 1(11), $117-121$.

Ahakannah, L.I.\& Chukwumezie, F. U. (2008). Office career development.

Alfred, O. A. (2014). Challenges of office technology and management courses and its implication on secretarial

profession. Nigerian Journal of Business Education, 1(3), 276-285.

Anigbogu, S.O. \& Anigbogu, G. N. (2010). An introduction to the fundamentals of computer science and information technology application. Awka: Christon International Company Limited.

Chukwukelu, E.P.\& Ile, C. M. (2018). Office competencies required of business education graduates for effective performance in modern offices in Imo State, Nigeria. Nau Journal of Technology and Vocational Education, 3(1), 54-62.

Chukwumezie, F. E. (2006). Computer skills needed by persnonnel secretarial assistants in private limited companies in south-eastern Nigeria. Nmandi Azikiwe University, Awka, Nigeria.

Garba, A. M. (2012). Self-assessment of Office technology and management students on computer applications in North-west Nigeria Polytechnics. Nnamdi Azikiwe University, Awka. 
Grace, F. O. (2015). Assessment of instructional facilities and equipment available of implementation of office technology and management program. Nigerian Journal of Business Education, 2(3), 200-212.

Haro, D.M.\& Nwazor, J. C. (2016). Supervisors rating of competencies possessed by office technology and management graduate workers in public organizations in Katsina State. Nau Journal of Technology and Vocational Education, 1(1), 163-172.

James, E. R. (1967). Supervisors role in personnel management. Association for Supervison and Curriculum www.ascd.org/ASCD/pdf/journals/ed_lead_/el/176712_rutrough.pdf

Microsoft. (2006). An introduction to Microsoft office. en.wikipedia.org/wiki/micorsoft_office

National Board for Technical Education (NBTE 2004). Office technology and management curriculum and course specifications.

Ndinechi, G.I. \& Ementa, C. N. (2013). Business education students rating of the teaching of word processing and desktop publishing skills in tertiary institutions in south-east, Nigeria. Nigerian Journal of Business Education, 1(2), 75-82.

Okolocha, C.C. \& Olanye, V. E. (2015). Supervisors' rating of word processing and spreadsheet competencies possessed by secretaries in government ministries in Delta State of Nigeria. Journal of Technology and Vocational Education, 1(2), 29-37.

Okoro, F. \& Asogwa, S. O. (2012). An analysis of contempoary challenges that confront secretries as perceived by office technology and management teachers in Bauchi State, Nigeria. Business Education Journal, 8(2), 16-29.

Okoye, P. O. (2012). Computer basics (4th ed.). Golden Eagle. 